Recepción: 20 / 04 / 2017

Aceptación: 20 / 05 / 2017

Publicación: 15 / 07 / 2017

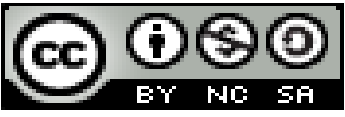

Ciencias Sociales

Artículo Científico

\title{
La espiritualidad y los espacios sagrados en las culturas aborígenes del litoral ecuatoriano
}

\author{
Spirituality and sacred spaces in the aboriginal \\ cultures of the ecuadorian littoral
}

\author{
Espaços espiritualidade e sagrados em \\ culturas aborígenes da costa equatoriana
}

Parsival E. Castro-Pita ${ }^{\mathrm{I}}$ parsival.castrop@ug.edu.ec

Ivetheyamel Morales-Vergara II ivetheyamel.moralesv.@ug.edu.ec

Ivonne A. Rendon-Jaluff III ivonne.rendonj@ug.edu.ec

Correspondencia: parsival.castrop@ug.edu.ec

Magister en Docencia y Gerencia en Educación Superior; Diploma Superior en Diseño Curricular por Competencias; Arquitecto Urbanista; Universidad de Guayaquil, Guayaquil, Ecuador.

II. Magister en Administración de Empresas con Mención en Marketing; Magister en Docencia y Gerencia en Educación Superior; Diploma Superior en Docencia y Evaluación en la Educación Superior; Arquitecta; Universidad de Guayaquil, Guayaquil, Ecuador.

III. Diploma Superior en Diseño Curricular por Competencias; Arquitecta; Universidad Guayaquil, Guayaquil, Ecuador. 


\section{Resumen}

La actual división política de los países, no coincide con la ocupación geográfica de las culturas aborígenes, que especialmente en los pueblos costeros tuvieron un riquísimo intercambio. Las expresiones estéticas, permiten pensar, que a más de un elemento utilitario, respondía a un trabajo psicológico del artesano, sobre sí mismo. En este orden de ideas el símbolo artístico toma un valor de auto revelación, el lenguaje que podía expresar lo Sagrado $($ Sat = luz - grado = nivel), es decir un grado de iluminación en la conciencia se lo llamó religioso. Los espacios sagrados en las sociedades tradicionales podían ser comprendidos de dos formas: la una proviniendo de las características geográficas del lugar, tales como un clima saludable, belleza del paisaje, presencia de corrientes magnéticas o brisas que estimulaban el sistema nerviosos y favorecían la actividad cerebral, la segunda, en función de las cosas que se hacían en un espacio. Se puede percibir que la sacralidad puede estar dada por ejemplo por la función de la cultura, el arte o la ciencia. Aquellos espacios o lugares eran denominados sagrados. Todo ello, estaba ligado a un entendimiento y una autorrealización personal, más que a un ramillete de creencias. En este trabajo se hace una revisión bibliográfica e históricas de estas manifestaciones de lo sagrado, entendido como el arte y la cultura de los aborígenes que habitaron las costas de lo que hoy conocemos como Ecuador, y la forma en que esta sacralidad influye en la forma de vida de quienes habitamos hoy en día, a partir del conocimiento y reconocimiento de esta cultura como nuestra.

Palabras clave: Sagrado; aborigen; espiritualidad; espacios. 


\section{Abstract}

The current political division of the countries does not coincide with the geographical occupation of Aboriginal cultures, which especially in the coastal towns had a very rich exchange. The aesthetic expressions, allow to think, that to more than a utilitarian element, it responded to a psychological work of the craftsman, on itself. In this order of ideas the artistic symbol takes on a value of self revelation, the language that could express the Sacred $($ Sat $=$ light - degree $=$ level), that is to say a degree of enlightenment in the conscience was called religious. Sacred spaces in traditional societies could be understood in two ways: one arising from the geographical characteristics of the place, such as a healthy climate, beauty of the landscape, presence of magnetic currents or breezes that stimulated the nervous system and favored brain activity, the second, according to the things that were done in a space. One can perceive that sacredness can be given for example by the function of culture, art or science. Those spaces or places were called sacred. All this was linked to a personal understanding and self-realization, rather than a bouquet of beliefs. In this work a bibliographical and historical revision of these manifestations of the sacred is made, understood as the art and the culture of the aborigines that inhabited the coasts of what today we know as Ecuador, and the way in which this sacredness influences the form of life of those we inhabit today, based on the knowledge and recognition of this culture as ours.

Keywords: Sacred; aboriginal; spirituality; spaces. 


\section{Resumo}

A política atual do país, a divisão não coincide com a ocupação geográfica das culturas aborígenes, especialmente nas cidades costeiras teve uma troca rica. expressões estéticas, permitem pensar que mais de um elemento utilitário, respondendo a um trabalho artesanal psicológico sobre si mesmo. Nesse sentido o símbolo artística assume um valor de auto-revelação, linguagem que pudesse expressar o sagrado $($ Sat $=$ luz - grau = nível $)$, ou seja, um grau de consciência de iluminação chamado religioso. espaços sagrados nas sociedades tradicionais poderia ser entendida de duas maneiras: uma vinda das características geográficas do local, tais como um clima saudável, bonita paisagem, a presença de correntes magnéticas ou brisas que estimulam o sistema nervoso e favorecendo a atividade cerebral o segundo, de acordo com as coisas que foram feitas em um espaço. Você pode ver que a santidade pode ser dada por exemplo a função da cultura, da arte ou da ciência. Esses espaços ou lugares foram chamados sagrado. Tudo isso estava ligado a uma compreensão e realização pessoal, em vez de um monte de crenças. Este trabalho apresenta uma revisão bibliográfica e histórica dessas manifestações do sagrado, entendida como a arte e cultura dos aborígenes que habitavam as margens do que é hoje conhecido como o Equador, e como isso influencia sagrados como é de vida daqueles que vivem hoje, a partir do conhecimento e reconhecimento desta cultura como a nossa.

Palavras chave: Espiritualidade; aborígene; sagrado; espaços. 


\section{Introducción}

La religiosidad de los pueblos se ha manifestado como un esfuerzo por comprender la totalidad de la existencia, de su entorno inmediato; la naturaleza y el universo.

A través de la diversidad de la vida y los fenómenos naturales, el ser humano percibía la unidad de la manifestación universal. Esa comprensión de la unidad constituyó la intuición de un estado superior de la existencia.

Muchas veces en esa búsqueda basó su ideal de felicidad. Para ello buscó religar todos los conocimientos que le proporcionaban las ciencias, las artes, la filosofía; aplicadas sobre sí mismo.

Esta actitud pasó a conocerse con el tiempo como religación o religión, del latín religare, entendida primordialmente como la unidad del saber que permitía comprender la totalidad de la vida. La ciencia era entendida entonces como el sentido ilimitado del Saber y no existía la división artificial del saber oficial, actualmente comprendido como el dominio de aquello que estrictamente aceptan las universidades y el resto del Saber.

La arquitectura fue al igual que otros manantiales de la cultura y la civilización la depositaría como lenguaje simbólico para expresar en el espacio la sacralidad de la vida.

La espiritualidad de los pueblos aborígenes del litoral ecuatoriano, se basaba más en la observación de la naturaleza; el cambio de sus estaciones, las cuales calendarizaban y provocaban reuniones que más que un carácter religioso tenían un carácter de estudios y conversaciones sobre una concepción filosófica de la existencia individual y colectiva.

Las comunidades americanas tenían una unidad cultural 
Una de las cosas que llamó la atención de los conquistadores es la unidad cultural que aunque con ligeras variantes ponían la nota de un denominador común en el continente, tales como formas agrícolas, vestuario similares, concepción simbólica de la naturaleza, forma de medir el tiempo, sistemas de numeración a través de cuerdas, y desarrollos metalúrgicos; en algunos casos de gran nivel.

Esta unidad cultural no siempre suponía una unidad política o formas de gobierno. Esa unidad cultural fue posible en virtud de superar barreras lingüísticas, raciales o tribales. A pesar de sus diferencias muchas veces se superó lo que modernamente se llamarían nacionalismos, que tanta división y conflictos han creado entre los pueblos.

La violencia exterior empieza con una violencia interna en virtud de reacciones mecánicas frente a las circunstancias sociales de la vida. La inteligencia, la lectura en el interior de las cosas, es aquello que comprendía la vida total. Las comunidades tradicionales discernían claramente que la astucia no era un signo de inteligencia.

Una misma tradición espiritual...

Una concepción de los orígenes unía las tradiciones, tanto de la América Andina, como la de los pueblos de la América Central. En la traducción que efectúa "Francisco Ximénez, cura doctrinero por el Real Patronato del Pueblo de Santo Tomás Chuila (actual Chichicastenango, Guatemala), del Popol Vuh, se lee en el capítulo primero:

"Todo estaba en suspenso, todo en calma, en silencio; todo inmóvil, callado, y vacía la extensión del cielo..." 
En el manuscrito quecha de comienzos del Siglo XVII, sobre los "Ritos y Tradiciones de

Huarochiri'”, encontrado en el Perú, se lee en el Capítulo primero:

"En el inicio del mundo, la oscuridad cubrió la tierra. Aquella sombra vacía aguardó el momento propicio para la expansión de la vida...”

Los centros ceremoniales en las costas del "Mar del Sur"...

Salazar (2001) indica que algunos sitios, como la Isla de la Plata y la Tolita (desembocadura del río Santiago) han sido considerados centros ceremoniales, que indudablemente tenían el poder de convocatoria para la celebración de ritos.

La liturgia de los pueblos aborígenes, evocaba el proceso cosmogónico de la naturaleza.

Seres de la naturaleza con cualidades físicas excepcionales como el jaguar, el caimán, la serpiente, el águila, la zarigüeya, el murciélago y otros, llegaron a expresar mucho más de lo que decía su propia realidad, porque ante el hombre, adquirieron una nueva significación. (Leiva, 1989)

Mas, es necesario insistir en que no se deben confundir los símbolos con los signos.

La cosmovisión del mundo aborigen de América

La cosmovisión de los pueblos de América consideraba al universo lleno de símbolos vivos. Así los relata el cronista Francisco de Jerez, secretario y escribano de Francisco Pizarro de la expedición que realizó al Perú en 1524. 
Los ritmos cósmicos ponían de manifiesto para estas culturas la manifestación de un orden, de una armonía universal, que revelaba los periodos de fecundidad de la tierra y el cambio de las estaciones. Así el cosmos era visto como un organismo real, vivo y sagrado.

(Cieza de León, 1948), relata:

Cuando se prendió a Atabalipa en la provincia de Caxamaica, hay vivos algunos cristianos que se hallaron con el marqués don Francisco de Pizarro, que lo prendió, que vieron en el cielo de media noche abajo una señal verde, tan gruesa como un brazo y tan largo como una lanza jineta; y como los españoles anduviesen mirando en ello, y Atabalipa lo entendiese, dicen que les pidió que lo sacasen para la ver, y como la vio, se paró triste y lo estuvo el día siguiente; y el gobernador don Francisco Pizarro le pr4eguntó que por qué se había parado triste.

- Respondió él: He mirado la señal del cielo y digote que cuando mi padre Guaynacapac murió se vio otra señal semejante a aquella”. Y dentro de quince días murió Atabalipa.

Esta idea de un universo vivo y simbolizado coincidencialmente existió en Europa, sostenida por mentes ilustres como Isaac Newton, el físico Johan Kepler y el escritor Santo Tomás de Aquino.

Algunos de los espacios sagrados que aún se encuentran

En el camino a Sacachun y los círculos de piedra

Figura 1 Círculos de piedra en Sacachun muchos de ellos tiene el eje central alineado topográficamente Norte cero grados, cero minutos, cero segundos 


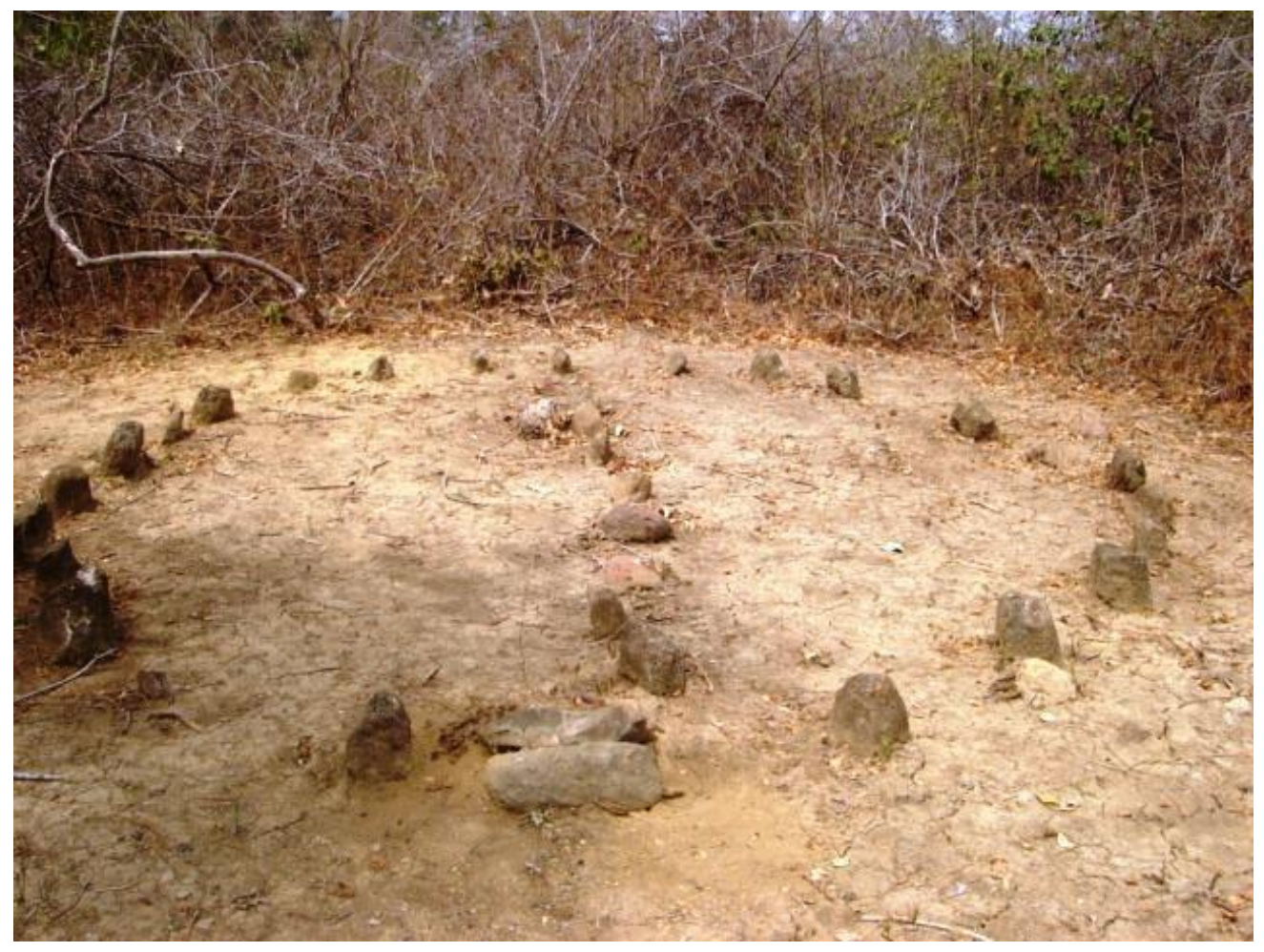

Fotografía de los autores

Las estelas encontradas medían alrededor de sesenta centímetros de alto y formaban círculos de cuatro metros de diámetro. Sus piedras son sedimentarias y perfectamente pulidas.

Los metates eran perfectamente rectangulares, es decir, hubo el conocimiento del ángulo recto o de noventa grados, pero tenían las puntas redondeadas, es decir, hubo una labor de pulida.

Hubo un sistema de medida

Y lo más sorprendente, se repite una vez más el modelo de círculos y una hilera que marca el diámetro, orientado - una vez más hay que repetirlo - al Norte a cero grados, cero minutos, cero segundos, lo cual revela que debió existir el instrumental para hacerlo: por tanto un saber transmitido, no solo por vía oral, sino que debió también existir un sistema de escritura. 
Si nuestras brújulas actuales y teodolitos, utilizan el norte magnético y corrigen el norte geográfico, significa que el instrumental utilizado por los constructores de círculos, efectuó la misma corrección.

En toda la región que comprende las poblaciones de Ciénaga, Las Juntas y Julio Moreno, existen círculos de piedras de similares características y en número abundante.

En los tiempos del reloj del Sol

Ambrosio Galo Tigrero Gonzabay, con sus noventa y dos años, es uno de los últimos viejos del pueblo. Desde su hamaca mira pasar los días mientras su mujer lava ropa en tina de pechiche.

El pechiche es una madera que resiste muy bien la humedad. Con su madera se hacían artísticas tinas con pequeños trozos de madera alrededor de un círculo que servía de plan, calado en el borde. Las pequeñas maderas estaban unidas por dos aros metálicos. Era una vieja artesanía aprendida de los tiempos en que con similar procedimiento, se fabricaban las ruedas para las carretas que tiraban los caballos.

En aquellos tiempos se guardaban con toda severidad las tradiciones religiosas. El ayuno de Semana Santa, era rigurosamente observado.

"Cada Viernes Santo, los mayores ponían una botella al sol, y esperaban hasta que no proyecte ninguna sombra, para probar el primer bocado del día”.

“Como generalmente, llovía tempestades para Semana Santa, se cubrían los espejos, y todos nos poníamos a rezar".

El cerro encantado y la contra para las culebras...! 
Don Francisco Lino comentaba de los círculos de piedras grandes que había visto más allá del ceibo grande. Relataba que en el Cerro de las Negras, la gente decía que el que se internaba podía ser presa de un encanto que le impedía regresar, a menos que lo hiciera de espaldas. Que mientras duraba el encanto, se veían construcciones fabulosas de piedra... Pero para verlas era necesario, textualmente, "primero perderse, caer en el encanto y entonces aparecían las visiones..."

La espiritualidad tradicional: una base común en diversas manifestaciones religiosas.

De la misma forma en que muchos templos cristianos fueron construidos sobre los basamentos de antiguos templos aborígenes, también en su visión del mundo se encuentran similitudes que traspasan el tiempo y las culturas.

Al comparar los diversos textos considerados sagrados por diversas culturas y civilizaciones, se observa similitud desde sus inicios, que en virtud de la analogía y el símbolo permite encontrar lazos de concordancia.

Así por ejemplo, en el capítulo primero del Popul Vuh, libro sagrado de la antiquísima civilización Maya se lee:

"No se manifestaba la faz de la tierra. Solo estaban el mar en calma y el cielo en toda su extensión.

No había nada junto que hiciera ruido, ni cosa alguna que se moviera, ni se agitara, ni hiciera ruido en el cielo.

No había nada que estuviera en pie; solo el agua en reposo, el mar apacible, solo y tranquilo. No había nada dotado de existencia.

Solamente había inmovilidad y silencio en la oscuridad, en la noche..." 
En el manuscrito, de Huarochiri, sobre las más antiguas tradiciones aborígenes peruanas, se lee en el capítulo primero: “Así fue en el comienzo: tinieblas y silencio. En el cielo, solo ausencia; ni luna ni estrellas, ni nubes. Y sobre la tierra...el vacío..."

En la Biblia cristiana se lee en el primer capítulo del Génesis versículo 2 "La tierra estaba informe y vacía y las tinieblas cubrían la superficie del abismo y el espíritu de Dios se movía sobre las $\operatorname{aguas...”}$

Si se puede advertir estas coincidencias en las expresiones de los libros denominadas sagrados para estas culturas, ocurrió también, en la arquitectura de varias ciudades de América, que los nuevos templos cristianos levantados por los conquistadores se construyeron muchas veces. Sobre los mismos cimientos de los adoratorios aborígenes. Ejemplo de ello es la Plaza del zócalo en Ciudad de México, Cuzco o las iglesias del Centro Histórico de Quito, construidos sobre santuarios indígenas.

La sacralidad en los pueblos del litoral

Para la comunidad Manteño-Huancavilca, la naturaleza no era exclusivamente geográfica, sino que estaba cargada de un valor espiritual. Todo su entorno lo concebían impregnado de sacralidad. Lo Sagrado se manifestaba en la propia estructura del mundo y los fenómenos naturales tales como la lluvia o el ritmo cambiante de las estaciones. Su contemplación a través de las reuniones en silencio en torno a un fuego simplemente les permitía contemplar la naturaleza esencial de la vida. Ello los volvía pueblos de Paz. En los enterramientos encontrados, se encuentran cuerpos completos y no mutilados lo que es propio de las guerras o la violencia social. El sacerdote dominico Fray Reginaldo de Lizárraga (1540-1609) describe que: "Viven en esta ciudad (Guayaquil) y su distrito dos naciones de indios, unos llamados guamcavillcas, gente bien dispuesta y blanca, limpios en sus vestidos y de buen parecer...!" 
Figura 2 Sello trabajado en cerámica de la cultura chorrera (-1000-500 antes de Cristo).

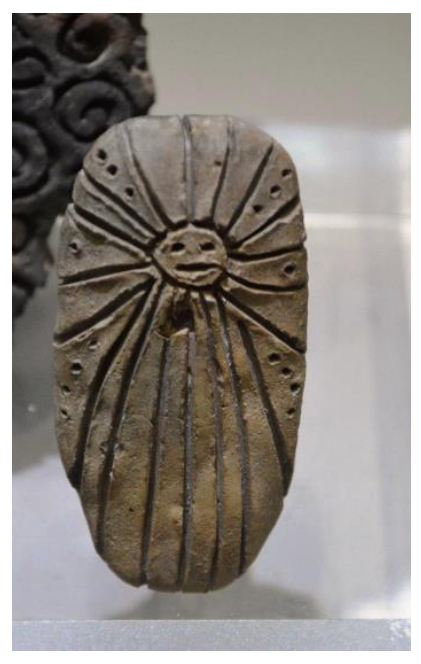

Cerámica chorrera (1000-500años antes de Cristo). Situada en el museo Presley Nortón, que ilustra la órbita oval de los planetas alrededor del sol que ocupa el lugar de uno de los focos de la elipse.. Se aprecia claramente el eje longitudinal que marca los solsticios de invierno y verano, Junio 21 y diciembre 22) así como los equinoccios de Primavera y otoño (Marzo 21-Septiembre 23) la cosmovisión de los pueblos del litoral comprendía los fenómenos del universo como manifestación de leyes que regularmente se cumplían cada año lo que les permitía determinar calendarios para la siembra y la cosecha. El advenimiento de las estaciones era celebrado con ceremoniales que muchas veces consistían simplemente en la reunión en silencio en torno a un fuego central. El movimiento de los planetas formaba para los aborígenes huancavilcas el gran ceremonial del universo.

La órbita elíptica de la tierra alrededor del sol está claramente descrita, como bien señalara siglos después el astrónomo alemán Johannes Kepler rectificando el concepto circular de Copérnico. La figura tiene 19 divisiones que coincide con los 19 años de los eclipses sáricos descubierto en Grecia por el astrónomo Saros. La figura se encuentra en el museo Presley Norton de Guayaquil.

Figura 3. Estela en piedra cultura manteño-huancavilca. Museo antropológico de Guayaquil 


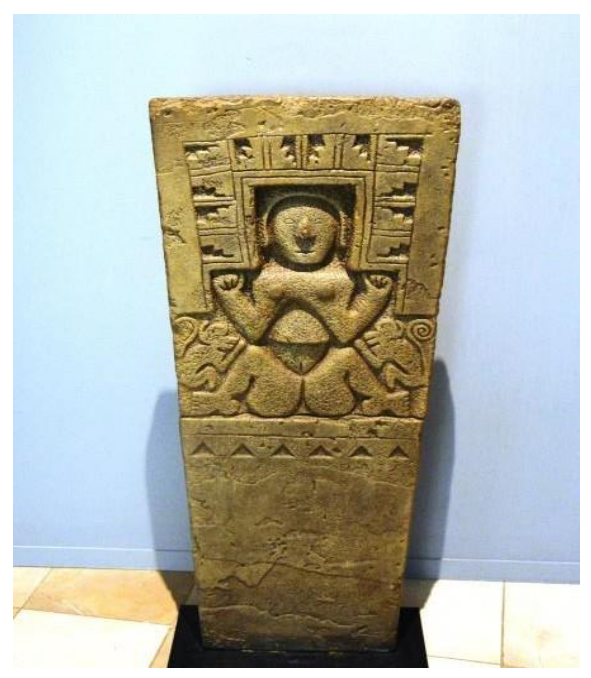

Se aprecia una mujer rodeada de una faja rectangular de 12 divisiones como los 12 meses del año. Los equinoccios y los solsticios constituían fechas de celebraciones. Era como recuperar con las fiestas la dimensión sagrada de la vida. A través de las fiestas se trascendía el tiempo histórico para vivir el tiempo mítico de la nueva creación del mundo en cada equinoccio.

Al igual que el sol que renacía en las estaciones del año, el ser humano podía imaginar un renacimiento en virtud de vivir una existencia nueva. Es posible que más allá de manifestaciones religiosa entendida en el sentido habitual contemporáneo, los pueblos aborígenes vivieran una práctica cultural en virtud de una espiritualidad diferente de la que trajeron los conquistadores.

\section{Materiales y Métodos}

Esta investigación fue realizada con el método etnográfico, histórico, analógico, usando algunas estrategias como las historias de vida, la narrativa y la revisión de las huellas históricas para su extrapolación al presente. 
Se llevó a cabo en los principales pueblos costeros de Ecuador, fundamentalmente Manta y Sacachum, donde mediante la interacción con sus habitantes se visitó cada uno de los lugares considerados sagrados desde la época precolombina.

Así mismo, se realizó una revisión bibliográfica de fuentes coloniales, con lo cual se comparó los escritos con las historias relatadas por los habitantes actuales de las regiones y la relación que estos tienen aun con los lugares sagrados de los aborígenes. Se levantó instrumentos como cuaderno de observación, registro fotográfico, filmación y grabación de testimonios.

\section{Conclusiones}

Al igual que muchas culturas antiguas se han encontrado manuscritos tales como los códices mayas, constituidos por folios, con inscripciones ideografías, es decir con ideas graficadas que constituían un lenguaje. Esto demuestra que nuestra cultura aborigen ya tenía nociones avanzadas de matemática, astronomía, etc. Lo cual les otorgaba, lo que hoy llamaríamos bases científicas a la cosmovisión, sobre la cual giraba la espiritualidad de los aborígenes.

Los lugares sagrados de las culturas aborígenes costeras, no eran un aposento particular, eran toda la naturaleza, el mundo completo, visto como un todo integral y luego representado en los sitios donde matemática y astronómicamente suponemos que se demostraba la "alienación" o sacralidad necesaria para la adoración de la naturaleza o lo sagrado en sí mismo. Viendo además toda manifestación cultural, artística y humana como un algo sagrado, demostrativo de la autorrealización con quien en la cultura actual llamamos Dios. 


\section{Bibliografía.}

Anónimo. Popol Vuh. Editorial EMU. Edición 2013.

Cieza de León, Pedro (1973). La Crónica del Perú. Reedición.

Leiva, María Soledad 1989. Guía Didáctica de "la Tolita”. Museo del Banco Central. Quito

Salazar, Ernesto (2001). Entre mitos y fábulas del Ecuador aborigen. Quito. 